Prepared in cooperation with Holmes County, Ohio

\title{
Development of Flood Profiles and Flood-Inundation Maps for the Village of Killbuck, Ohio
}

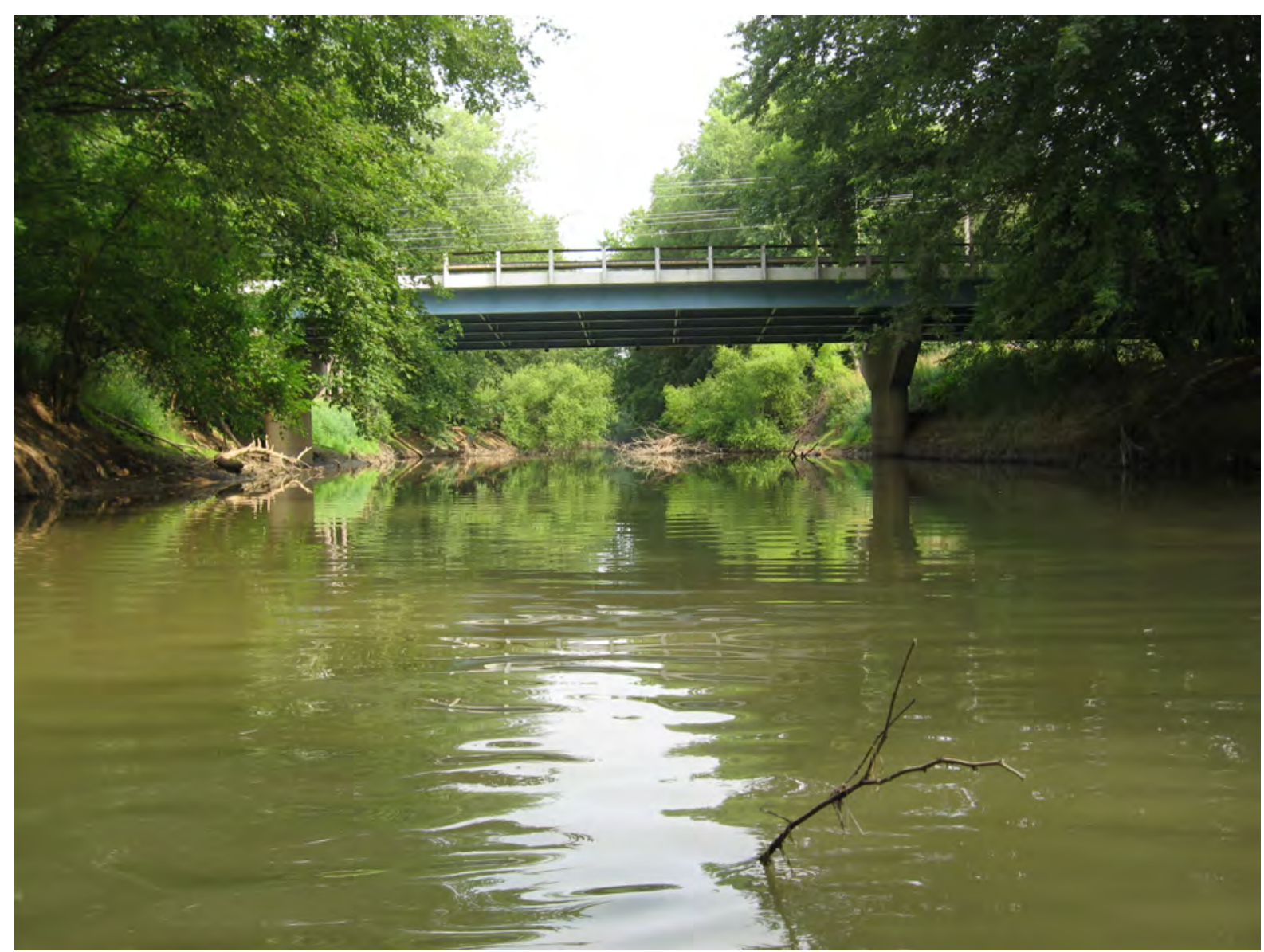

Open-File Report 2013-1032 
Cover photograph: U.S. Route 62 bridge over Killbuck Creek, just downstream from the Village of Killbuck, Ohio; view from middle of stream looking south at upstream bridge face (photo by Chad Ostheimer, U.S. Geological Survey). 


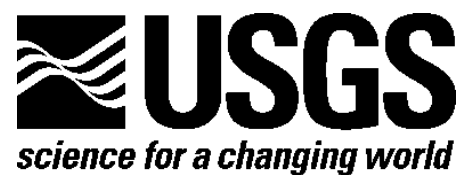

Prepared in cooperation with Holmes County, Ohio

\section{Development of Flood Profiles and Flood-Inundation Maps for the Village of Killbuck, Ohio}

By Chad J. Ostheimer

Open-File Report 2013-1032

U.S. Department of the Interior

U.S. Geological Survey 


\section{U.S. Department of the Interior \\ KEN SALAZAR, Secretary}

\section{U.S. Geological Survey \\ Suzette M. Kimball, Acting Director}

U.S. Geological Survey, Reston, Virginia: 2013

For more information on the USGS-the Federal source for science about the Earth, its natural and living resources, natural hazards, and the environment-visit http://www.usgs.gov or call 1-888-ASK-USGS

For an overview of USGS information products, including maps, imagery, and publications, visit $h$ ttp://www.usgs.gov/pubprod

To order this and other USGS information products, visit $h$ ttp://store.usgs.gov

Suggested citation:

Ostheimer, C.J., 2013, Development of flood profiles and flood-inundation maps for the Village of Killbuck, Ohio: U.S. Geological Survey Open-File Report 2013-1032, 8 p., http://pubs.usgs.gov/of/2013/1032/.

Any use of trade, firm, or product names is for descriptive purposes only and does not imply endorsement by the U.S. Government.

Although this information product, for the most part, is in the public domain, it also may contain copyrighted materials as noted in the text. Permission to reproduce copyrighted items must be secured from the copyright owner. 


\section{Contents}

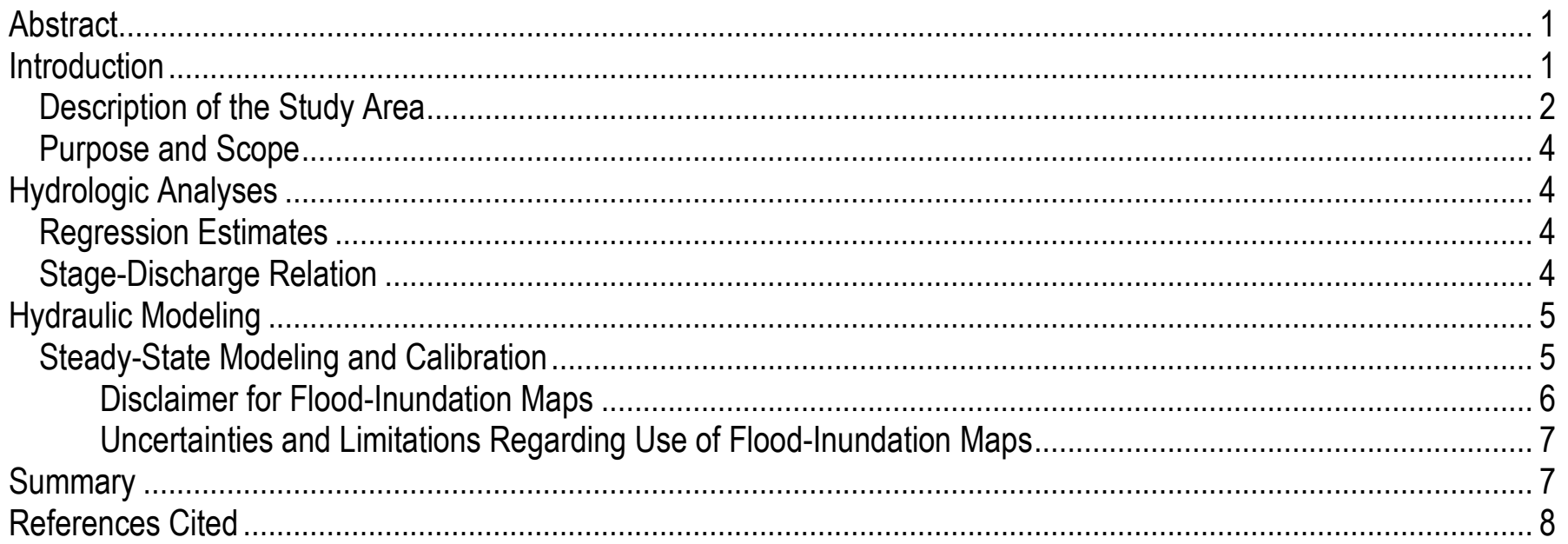

\section{Figures}

Figure 1. Map of study area showing Killbuck Creek, its major tributaries, and the Village of Killbuck, Ohio....... 3

\section{Tables}

Table 1. Summary of existing Federal Emergency Management Agency Flood Insurance Studies

(FIS) for selected streams in Holmes County

Table 2. Summary of Killbuck Creek basin characteristics applied in the regression equations.

Table 3. Summary of gage-weighted flood-peak discharge estimates and rating- derived discharges for selected National Weather Service designated stages at USGS streamgage Killbuck Creek near Killbuck (03139000)

Table 4. Summary of final Manning's roughness coefficients used in the hydraulic model. 6 


\section{Conversion Factors}

\begin{tabular}{lcl}
\hline & \multicolumn{1}{c}{ Multiply } & \multicolumn{1}{c}{ To obtain } \\
\hline foot $(\mathrm{ft})$ & Length & \\
mile $(\mathrm{mi})$ & 0.3048 & meter $(\mathrm{m})$ \\
\hline & 1.609 & kilometer $(\mathrm{km})$ \\
\hline square mile $\left(\mathrm{mi}^{2}\right)$ & Area & \\
\hline & 2.590 & square kilometer $\left(\mathrm{km}^{2}\right)$ \\
\hline cubic foot per second $\left(\mathrm{ft}^{3} / \mathrm{s}\right)$ & Flow rate & \\
\hline & 0.02832 & cubic meter per second $\left(\mathrm{m}^{3} / \mathrm{s}\right)$ \\
\hline foot per mile $(\mathrm{ft} / \mathrm{mi})$ & Hydraulic gradient & \\
\hline
\end{tabular}

Vertical coordinate information is referenced to the North American Vertical Datum of 1988 (NAVD 88).

Horizontal coordinate information is referenced to the North American Datum of 1983 (NAD 83).

Elevation, as used in this report, refers to distance above the vertical datum. 


\title{
Development of Flood Profiles and Flood-Inundation Maps for the Village of Killbuck, Ohio
}

\author{
By Chad J. Ostheimer
}

\begin{abstract}
Digital flood-inundation maps for a reach of Killbuck Creek near the Village of Killbuck, Ohio, were created by the U.S. Geological Survey (USGS), in cooperation with Holmes County, Ohio. The inundation maps depict estimates of the areal extent of flooding corresponding to water levels (stages) at the USGS streamgage Killbuck Creek near Killbuck (03139000) and were completed as part of an update to Federal Emergency Management Agency Flood-Insurance Study. The maps were provided to the National Weather Service (NWS) for incorporation into a Web-based flood-warning system that can be used in conjunction with NWS flood-forecast data to show areas of predicted flood inundation associated with forecasted flood-peak stages. The digital maps also have been submitted for inclusion in the data libraries of the USGS interactive Flood Inundation Mapper. Data from the streamgage can be used by emergency-management personnel, in conjunction with the flood-inundation maps, to help determine a course of action when flooding is imminent.

Flood profiles for selected reaches were prepared by calibrating a steady-state step-backwater model to an established streamgage rating curve. The step-backwater model then was used to determine water-surface-elevation profiles for 10 flood stages at the streamgage with corresponding streamflows ranging from approximately the 50- to 0.2 -percent annual exceedance probabilities. The computed flood profiles were used in combination with digital elevation data to delineate flood-inundation areas.
\end{abstract}

\section{Introduction}

The development of this set of flood profiles and flood-inundation maps originated in July 2007 as an update to the 1986 Federal Emergency Management Agency (FEMA) Flood Insurance Study (FIS) for the Village of Killbuck, Ohio (Federal Emergency Management Agency, 1986, 1990) (table 1). Discussions between the U.S. Geological Survey (USGS), the Village of Killbuck, and the Holmes County Engineer's Office resulted in the prioritization of tasks and adoption of a scope of work for this study effort. A single stream reach of Killbuck Creek was selected for study within Holmes County. The USGS was tasked to develop a step-backwater model and generate digital flood boundaries for the 50-, 20-, 10-, 4-, 2-, 1-, and 0.2-percent annual exceedance probability (AEP) flood profiles for Killbuck Creek.

Subsequent discussions were held with the National Weather Service (NWS) concerning the development of a flood warning system (FWS) for the Village of Killbuck. The system consists of NWS flood forecasts based on data from USGS streamgage Killbuck Creek near Killbuck (03139000) and a family of flood-boundary shapefiles ${ }^{1}$. The corresponding flood-boundary shapefile nearest to the NWS predicted peak was to be served on the NWS Web site. As a result of the NWS discussions, the project

\footnotetext{
${ }^{1}$ Shapefiles are actually groups of files sharing a common root file name. Shapefiles minimally consist of a main file, an index file, and a database file. Geometric features are stored as a set of vector coordinates with associated attribute information. Shapefiles do not explicitly store topological relationships.
} 
scope was expanded to include three additional profiles corresponding to National Weather Service designated stages of flood stage, moderate flood stage, and major flood stage. All work was completed in March 2008. The shapefiles have since been submitted for inclusion in the data libraries of the USGS interactive Flood Inundation Mapper (http://wim.usgs.gov/FIMI/).

Table 1. Summary of existing Federal Emergency Management Agency Flood Insurance Studies (FIS) for selected streams in Holmes County.

\begin{tabular}{ccccc}
\hline $\begin{array}{c}\text { Stream } \\
\text { name }\end{array}$ & FIS date & Study name & $\begin{array}{c}\text { Community } \\
\text { number }\end{array}$ & $\begin{array}{c}\text { Level of } \\
\text { study }\end{array}$ \\
\hline Killbuck Creek & 1986 & Village of Killbuck, Ohio, Holmes County ${ }^{1}$ & 390279 & Detailed \\
\hline & & & 390277 & \\
Killbuck Creek & \multirow{2}{*}{1990} & Holmes County, Ohio, and incorporated Areas & 390278 & \\
& & & 390279 & Detailed \\
& & & 390280 & \\
& & 390276 & \\
\hline
\end{tabular}

${ }^{1}$ The 1986 Village of Killbuck FIS was later republished as part of the 1990 Holmes County FIS.

\section{Description of the Study Area}

Holmes County, located in northeast-central Ohio approximately 55 miles northeast of Columbus (fig. 1), covers approximately 424 square miles and has an estimated population of 42,000 (U.S. Census Bureau, 2010). The Village of Killbuck has an estimated population of 800, making it the third largest community within Holmes County. Holmes County is in the Appalachian Plateaus physiographic province and is split between the Glaciated Allegheny Plateaus section in the north and Unglaciated Allegheny Plateaus section in the south (Ohio Division of Geological Survey, 1998). The relief in Holmes County varies with location (gently rolling hills in the north to steep slopes and ridges in the south) with altitudes ranging from about 790 to 1,410 feet. The county is predominantly rural, with about two-thirds of the land in use for crops and pasture. Approximately 60 percent of Holmes County drains to Killbuck Creek (a tributary of the Walhonding River). The remaining area of Holmes County drains to other tributaries of the Walhonding River and to tributaries of the Tuscarawas River. The Walhonding and Tuscarawas Rivers join to form the Muskingum River, which drains to the Ohio River. Study-reach limits for Killbuck Creek are shown in figure 1. 


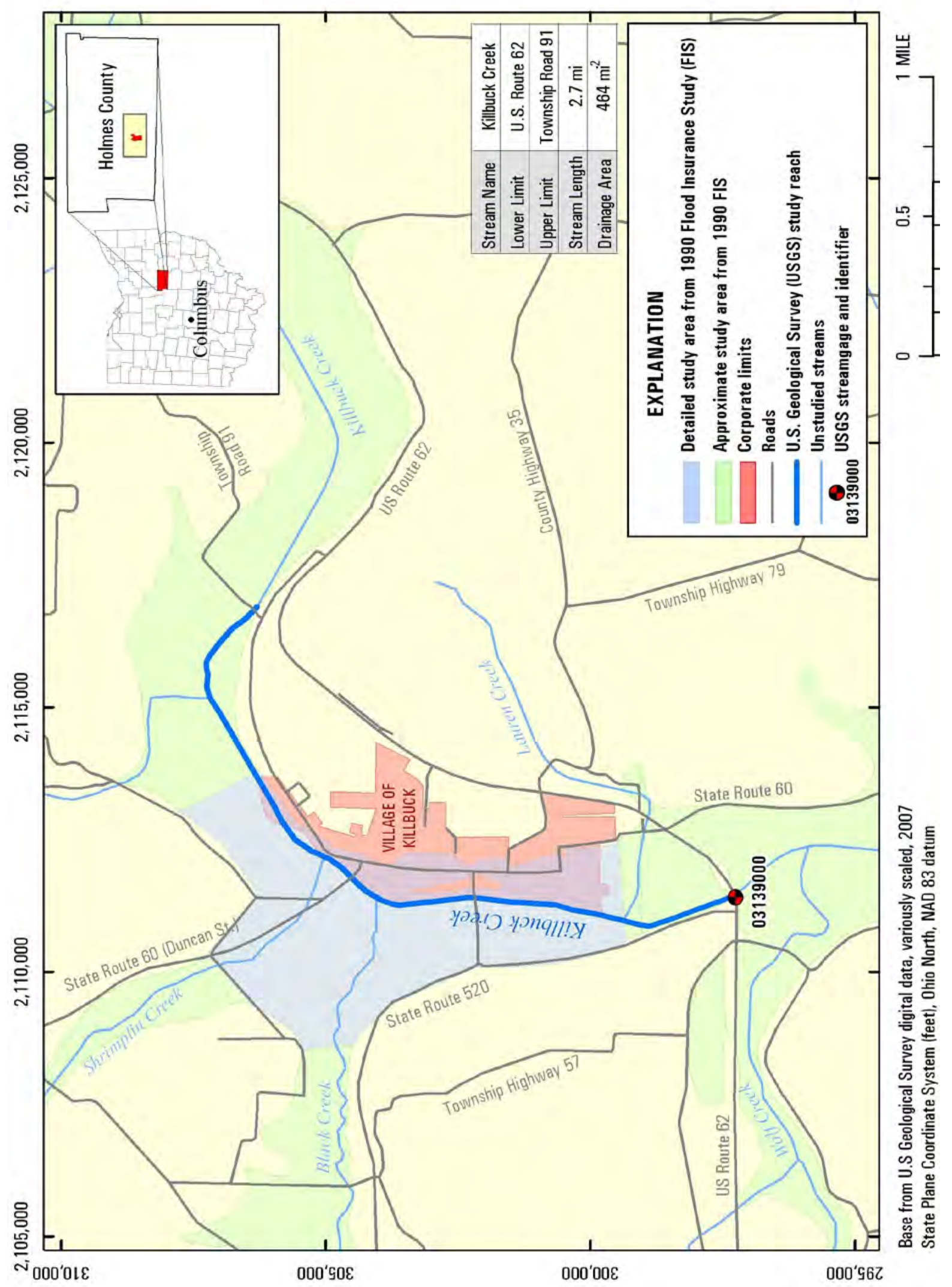

Figure 1. Map of study area showing Killbuck Creek, its major tributaries, and the Village of Killbuck, Ohio. 


\section{Purpose and Scope}

The purpose of this report is to describe the development of a series of estimated floodinundation maps for Killbuck Creek near Killbuck, Ohio. The maps and other useful flood information are available on the USGS Flood Inundation Mapping Science Web site (http://wim.usgs.gov/FIMI/) and the NWS Advanced Hydrologic Prediction Service Web site (http://water.weather.gov/ahps2/hydrograph.php?wfo=cle\&gage=kilo1). Internet users can select estimated inundation maps that correspond to (1) current stages at the USGS streamgage, (2) the NWS forecasted peak stage, or (3) other desired stream stages.

\section{Hydrologic Analyses}

The USGS determined 10 flood profiles for Killbuck Creek. Seven flood profiles were for estimates of the 50-, 20-, 10-, 4-, 2-, 1-, and 0.2-percent AEP flood-peak discharges. The three remaining flood profiles were determined for discharges corresponding to NWS designated stages of flood stage, moderate flood stage, and major flood stage.

No reduction in flow was made for the reach of Killbuck Creek upstream from Shrimplin Creek. The drainage area of Shrimplin Creek (10.1 square miles) is small compared to the drainage area of Killbuck Creek above Shrimplin Creek (416 square miles). The difference in discharge estimates for Killbuck Creek downstream and upstream from the confluence with Shrimplin Creek were assumed to be insignificant. This assumption also provides a conservative solution for computation of the flood profiles affecting the northern limits of the Village of Killbuck.

\section{Regression Estimates}

Estimates of the 50-, 20-, 10-, 4-, 2-, 1-, and 0.2-percent AEP flood-peak discharges for Killbuck Creek are those published by Koltun and others (2006). That report also describes the methods used to determine the estimates. To compute peak-discharge estimates using the methods described, drainage area (in square miles), main channel slope (in feet per mile), and percentage of the basin defined as water or wetlands are applied to multiple-regression equations that are presented in Koltun and others (2006). These basin characteristics are determined by using a geographic information system (GIS) and applying methods described in Koltun and others (2006). The percentage of the basin classified as water or wetlands that is required for the multiple-regression equations is defined as the percentage of the drainage area designated as wetlands or open water in the 1992 National Land Cover Dataset (U.S. Geological Survey, 2000) compared to the total drainage area of the basin.

All flood-peak discharge regression-equation estimates were then gage weighted by using techniques described in Koltun and others (2006), in combination with 71 years of streamgage data from Killbuck Creek near Killbuck (03139000) from 1931 to 2001. The basin characteristics applied in the regression equations, as well as the resulting gage-weighted flood-peak discharges estimates for Killbuck Creek, are presented in tables 2 and 3, respectively.

\section{Stage-Discharge Relation}

For the NWS designated stages, discharge estimates corresponding to flood stage (15.00 feet), moderate flood stage (17.00 feet), and major flood stage (18.50 feet) were determined from the stagedischarge relation (rating 42) for USGS streamgage Killbuck Creek near Killbuck, Ohio (03139000). The estimated flood-peak discharges for flood stage, moderate flood stage, and major flood stage were determined to be $1,800,5,100$, and 12,300 cubic feet per second, respectively. The results are listed in table 3 . 
Table 2. Summary of Killbuck Creek basin characteristics applied in the regression equations.

\begin{tabular}{cccc}
\hline $\begin{array}{c}\text { Location } \\
\text { description }\end{array}$ & $\begin{array}{c}\text { Drainage area, } \\
\text { square miles }\end{array}$ & $\begin{array}{c}\text { Main-channel slope, } \\
\text { feet per mile }\end{array}$ & $\begin{array}{c}\text { Water or } \\
\text { wetland area, } \\
\text { percent }\end{array}$ \\
\hline At USGS streamgage $(03139000)$ & 464 & 3.62 & 2.54 \\
\hline
\end{tabular}

Table 3. Summary of gage-weighted flood-peak discharge estimates and ratingderived discharges for selected National Weather Service designated stages at USGS streamgage Killbuck Creek near Killbuck (03139000).

[AEP, Annual Exceedance Probability; NWS, National Weather Service; $\mathrm{ft}^{3} / \mathrm{s}$, cubic feet per second]

\begin{tabular}{ccccc}
\hline AEP & $\begin{array}{c}\text { NWS } \\
\text { designated stage }\end{array}$ & $\begin{array}{c}\text { Discharge, } \\
\text { in } \mathrm{ft}^{3} / \mathbf{s}\end{array}$ & $\begin{array}{c}\text { Stage, } \\
\text { in feet }\end{array}$ & $\begin{array}{c}\text { Elevation, } \\
\text { in feet }\end{array}$ \\
\hline \multirow{2}{*}{ 50 percent } & Flood & 1,800 & 15.00 & 802.21 \\
& & 3,410 & 16.50 & 803.71 \\
20 percent & Moderate flood & 5,100 & 17.00 & 804.21 \\
10 percent & & 5,510 & 17.11 & 804.32 \\
4 percent & & 7,420 & 17.53 & 804.74 \\
& & 10,600 & 18.18 & 805.39 \\
2 percent & Major flood & 12,300 & 18.50 & 805.71 \\
1 percent & & 13,500 & 18.73 & 805.94 \\
0.2 percent & & 16,900 & 19.28 & 806.49 \\
\hline
\end{tabular}

\section{Hydraulic Modeling}

The hydraulic analyses were done with U.S Army Corps of Engineers Hydrologic Engineering Center-River Analysis System (HEC-RAS), version 3.1.1 (U.S. Army Corps of Engineers, 2003). HECRAS is a one-dimensional step-backwater model used to compute water-surface profiles with steady- or unsteady-state flow computation options. HEC-RAS is accepted by FEMA for use in the National Flood Insurance Program (NFIP). All hydraulic analyses for this report were done with the steady-state flow computation option.

\section{Steady-State Modeling and Calibration}

The initial starting boundary condition for each flood profile was stage determined from a slope conveyance calculation. The energy slope was estimated from the average streambed slope as determined from field surveys. Initial modeling began approximately 2,200 feet downstream from U.S. Route 62. Streamflows were then routed upstream to the upper limit at Township Road 91. The model was calibrated by changing the Manning's roughness coefficients from original field estimates until the results of the hydraulic computations closely agreed with known flood-streamflow stage values. Manning's roughness coefficients were held constant for the overbank areas but varied in the channel as a function of discharge. Ranges of final Manning's roughness coefficients are listed in table 4 . 
Table 4. Summary of final Manning's roughness coefficients used in the hydraulic model.

[AEP, Annual Exceedance Probability; NWS, National Weather Service; $\mathrm{ft}^{3} / \mathrm{s}$, cubic feet per second]

\begin{tabular}{|c|c|c|c|c|c|c|}
\hline \multirow{3}{*}{ AEP } & \multirow{3}{*}{$\begin{array}{c}\text { NWS } \\
\text { designated } \\
\text { stage }\end{array}$} & \multirow{3}{*}{$\begin{array}{c}\text { Discharge, } \\
\text { in } \mathrm{ft}^{3} / \mathrm{s}\end{array}$} & \multicolumn{4}{|c|}{ Manning's roughness coefficients } \\
\hline & & & \multicolumn{2}{|c|}{ Stream channel } & \multicolumn{2}{|c|}{ Overbanks } \\
\hline & & & Minimum & Maximum & Minimum & Maximum \\
\hline & Flood & 1,800 & 0.048 & 0.058 & \multirow{10}{*}{0.032} & \multirow{10}{*}{0.096} \\
\hline \multirow[t]{2}{*}{ 50-percent chance } & & 3,410 & 0.048 & 0.058 & & \\
\hline & Moderate flood & 5,100 & 0.047 & 0.057 & & \\
\hline 20-percent chance & & 5,510 & 0.047 & 0.056 & & \\
\hline 10-percent chance & & 7,420 & 0.046 & 0.055 & & \\
\hline \multirow[t]{2}{*}{ 4-percent chance } & & 10,600 & 0.045 & 0.052 & & \\
\hline & Major flood & 12,300 & 0.044 & 0.051 & & \\
\hline 2-percent chance & & 13,500 & 0.044 & 0.050 & & \\
\hline 1-percent chance & & 16,900 & 0.042 & 0.047 & & \\
\hline 0.2-percent chance & & 27,900 & 0.038 & 0.038 & & \\
\hline
\end{tabular}

After the Manning's roughness coefficients were calibrated, the hydraulic model was shortened so that the new lower limit was at the USGS Killbuck Creek at Killbuck (03139000) streamgage. The starting boundary condition for each flood profile was then set to be a known water-surface elevation obtained from the stage-discharge relation (rating 42) for Killbuck Creek near Killbuck, Ohio (03139000) (table 3). Stages were converted to NAVD 88 by adding the gage datum of 787.21 feet.

\section{Development of Flood-Inundation Maps}

Flood-inundation areal boundaries were initially mapped with HEC-GeoRAS software (U.S. Army Corps of Engineers, 2002). USGS personnel modified the HEC-GeoRAS results to ensure a logical transition of the flood-inundation boundary between modeled cross sections based on elevation contour data for the land surface. The flood-inundation boundaries then were overlain onto digital orthophotos from the Ohio Statewide Imaging Program (OSIP, Ohio Geographically Referenced Information Program, 2007). The resulting estimated flood-inundation boundaries can be found at the USGS Flood Inundation Mapping Science Web site (http://wim.usgs.gov/FIMI/) and the NWS Advanced Hydrologic Prediction Service Web site (http://water.weather.gov/ahps2/hydrograph.php?wfo=cle\&gage=kilo1).

\section{Disclaimer for Flood-Inundation Maps}

Inundated areas shown should not be used for navigation, regulatory, permitting, or other legal purposes. The USGS provides these maps "as-is" for a quick reference, emergency planning tool but assumes no legal liability or responsibility resulting from the use of this information. 
Although the flood-inundation maps represent the boundaries of inundated areas with a distinct line, some uncertainty is associated with these maps. The flood boundaries shown were estimated based on water stages and streamflows at selected USGS streamgages. Water-surface elevations along the stream reaches were estimated by steady-state hydraulic modeling, assuming unobstructed flow, and using streamflows and hydrologic conditions anticipated at the USGS streamgage(s). The hydraulic model reflects the land-cover characteristics and any bridge, dam, levee, or other hydraulic structures existing as of December 2007. Unique meteorological factors (timing and distribution of precipitation) may cause actual streamflows along the modeled reach to vary from those assumed during a flood, which may lead to deviations in the water-surface elevations and inundation boundaries shown. Additional areas may be flooded due to unanticipated conditions such as: changes in the streambed elevation or roughness, backwater into major tributaries along a main stem river, or backwater from localized debris or ice jams. The accuracy of the floodwater extent portrayed on these maps will vary with the accuracy of the DEM used to simulate the land surface. Additional uncertainties and limitations pertinent to this study may be described elsewhere in this report.

If this series of flood-inundation maps will be used in conjunction with NWS river forecasts, the user should be aware of additional uncertainties that may be inherent or factored into NWS forecast procedures. The NWS uses forecast models to estimate the quantity and timing of water flowing through selected stream reaches in the United States. These forecast models (1) estimate the amount of runoff generated by precipitation and snowmelt, (2) simulate the movement of floodwater as it proceeds downstream, and (3) predict the flow and stage (and water-surface elevation) for the stream at a given location (AHPS forecast point) throughout the forecast period (every 6 hours and 3 to 5 days out in many locations). For more information on AHPS forecasts, please see: http://water.weather.gov/ahps/pcpn_and_river_forecasting.pdf.

\section{Summary}

A flood-warning system was developed for the Village of Killbuck in Holmes County, Ohio, by the delineation of flood-inundation boundaries that correspond to selected flood stages. Water-surface profiles were estimated by use of a steady-state step-backwater model, and corresponding floodinundation areal boundaries were delineated for 10 stages at U.S. Geological Survey (USGS) streamgage Killbuck Creek near Killbuck (03139000). Seven of the stages were tied to the 50-, 20-, 10-, 4-, 2-, 1-, and 0.2-percent annual exceedance probability floods. The remaining three stages were for National Weather Service (NWS) designated stages of flood stage, moderate flood stage, and major flood stage. The flood-inundation boundaries were overlain on digital orthophotos.

Real-time streamgage, flood-forecast predictions, and flood-inundation mapping corresponding to flood forecasts can be accessed on Web sites hosted by the USGS and the NWS. It is expected that the increased amount and availability of publically accessible streamflow data, along with enhanced flood-prediction capability, will improve the ability of public and emergency-management officials to assess flood conditions, take appropriate steps to protect life and property, and reduce flood damage. 


\section{References Cited}

Federal Emergency Management Agency, 1986, Flood Insurance Study, Village of Killbuck, Ohio, Holmes County, Community Number 390279, February 5, 1986 [variously paged].

Federal Emergency Management Agency, 1990, Flood Insurance Study, Holmes County, Ohio, and Incorporated Areas, Community Numbers 390277, 390278, 390279, 390280, and 390276, December 15,1990 [variously paged].

Koltun, G.F., Kula, S.P., and Puskas, B.M., 2006, A Streamflow Statistics (StreamStats) Web application for Ohio: U.S. Geological Survey Scientific Investigations Report 2006-5312, 62 p.

Ohio Division of Geological Survey, 1998, Physiographic regions of Ohio: Page-size map with text, 2 p., scale 1:2,100,000.

Ohio Geographically Referenced Information Program, 2007, Ohio Statewide Imagery Program, Licking County, accessed May 29, 2012, at http://gis3.oit.ohio.gov/geodata/.

U.S. Army Corps of Engineers-Hydrologic Engineering Center, 2002, HEC-GeoRAS, accessed February 5, 2013, at URL http://www.hec.usace.army.mil/software/hec-ras/hec-georas.html.

U.S. Army Corps of Engineers-Hydrologic Engineering Center, 2003, HEC-RAS River Analysis System, user's manual, Version 3.1.1 [variously paged].

U.S. Census Bureau, 2010, City and town totals, Vintage 2011-Minor Civil Divisions, 2010 to 2011, Ohio (SUB-EST2011-04-39.xsl), accessed February 5, 2013, at http://www.census.gov/popest/data/cities/totals/2011/index.html.

U.S. Geological Survey, 2000, National Land Cover Dataset: U.S. Geological Survey Fact Sheet FS108-00, accessed February 5, 2013, at http://erg.usgs.gov/isb/pubs/factsheets/fs10800.html. 


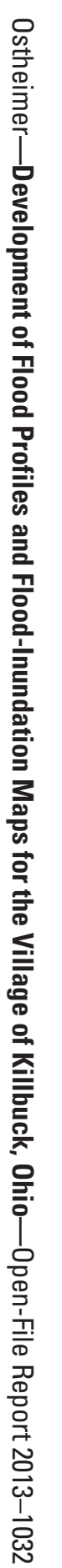

